DOI: $10.1515 /$ rpp-2015-0053

Doctor of Pedagogical Sciences, Full Professor, MARIA LESHCHENKO Institute of Information Technologies and Educational Means, NAPS of Ukraine Address: 9 M. Berlynskoho St., Kyiv, 04060, Ukraine E-mail: darlingpetra@gmail.com

$\mathrm{PhD}$ in Pedagogical Sciences, Senior Researcher, NATALIYA AVSHENYUK Institute of Pedagogical and Adult Education, NAPS of Ukraine Address: 9 M. Berlynskoho St., Kyiv, 04060, Ukraine E-mail: nataliya.avshenyuk@gmail.com

\title{
PHILOSOPHICAL AND PEDAGOGICAL PRINCIPLES OF TRANSNATIONAL HIGHER EDUCATION DEVELOPMENT
}

\begin{abstract}
The philosophical and pedagogical principles of transnational higher education development in the second half of the XX - at the beginning of the XXI century are revealed based on the authentic scientific research sources and reflections of prominent scientists. Review of scientific works, devoted to the problems of education transnationalization, allowed concluding that in the late XX century the traditional relationship of pedagogy and philosophy changed under the influence of globalization and internationalization of education. On the basis of determinant analysis it has been found that postmodernism (J. Derrida, M. Foucault, J. Lyotard, R. Panvit) and postnonclassical science (H. Haken, I. Prihozhyn, V. Stepin) serve philosophical grounds for transnational higher education formation. The article proves that the "philosophy of global problems" as a set of ideas based on the objectivity of the total global relations, serves as the basis for building a modern educational paradigm that is reflected in the concept of global education. The fundamental idea of global education is to develop a holistic vision and human perception of the world, awareness of its place in the interconnected and rapidly changing environment, by filling content of educational process with human values. Practical implementation of these ideas is made by the introduction of multicultural education approach, critical pedagogy, global education and formation of intercultural educational content, which reflects the cultural and historical specificity of population.

Key words: globalization, postmodernism, postnonclassical science, philosophy of global problems, transnationalization of education, global education, critical pedagogy, development of intercultural sensitivity.

\section{INTRODUCTION}

At the beginning of the XXI century the necessity of finding ways to acquire human ability to understand, live and act in a holistic world encourage philosophical thought to rethink the nature of higher education to the aggravation of the current global problems that threaten the existence of mankind, in particular, issues of environmental and social character, problems of world perception both as diversity and a whole, where the actions of each person depend on the welfare of the whole community. Traditional knowledgelearning model, focused on the mastery of knowledge and skills, gradually comes into conflict with the goals and objectives of transnational education aimed at training professionals able to solve the universal problem in heterogeneous professional environment, ready to lifelong learning in different social and cultural contexts.
\end{abstract}




\section{THE AIM OF THE STUDY}

The purpose of research consists in revealing philosophical and pedagogical principles of transnational higher education development in the second half of the XX - at the beginning of the XXI century on the basis of determinant analysis.

\section{THEORETICAL FRAMEWORK AND RESEARCH METHODS}

The conceptual idea of the study is based on understanding of transnational higher education as a multidisciplinary educational category that integrates specific provisions of such scientific fields as pedagogy and philosophy. We share the view of contemporary philosophers of education on the fundamental importance of the relationship of pedagogy with philosophy as an external factor that defines the conceptual model of knowledge, as well as with educational practice that embodies ideas in everyday pedagogical training, particularly as with established educational systems in general. Being a deep form of pedagogical reflection, philosophy of education determines the place of education in society life and a man formation, explores system integrity of education within semantic and procedural aspects and voices the challenges of time. Goals, ideals and values of education in modern society, their relationship with technologies and means of education and training, coordination of social criteria for evaluating the results of education with the needs for social development come to the attention of educational philosophy (Вознюк, Дубасенюк, 2009).

Based on multidisciplinary research Ukrainian philosophers in the late XX century developed a number of concepts that could be the grounds for philosophical and pedagogical justification of transnational higher education, including educational synergy, postnonclassical education (V. Kyzyma, V. Lukyanets, V. Lutay, V. Onopriyenko); neosphere education (N. Maslov, V. Pozdnyakov), philosophical integrative education that is based on the phenomenological and hermeneutical principles of communicative rationality (R. Artsyshevskyy); transdisciplinary of postnonclassical, synergetic societal education (L. Gubernsky, V. Kremen), based on the principles of self-organization, self-development, integrity of social, humanitarian and natural disciplines (Поздняков, 2004).

\section{RESULTS}

According to the survey results G. Shaton, who considers the formation of pedagogy influenced by philosophical concepts for centuries, pedagogical theory developed relative independence, going a long way from rationalism to postmodern (Шатон, 2013). In the previous era (before postmodernism) pedagogy formed as knowledge, defined by philosophical reflection of reality in which education according to G. Hegel is "ascent to the general". Educational practice had only indirect influence on the development of pedagogical science, it served as an area for new pedagogical ideas forming, and often dramatically behind the pedagogical theory. Rational-pragmatic pedagogy of J. Dewey, reflecting the intrinsic features of the philosophy of rationalism, largely determined the formation of the educational system of the XX century and practices of educational institutions and society relationships. The next important step in the development of educational theory became postmodernism, grounded in the 1960 by J. Lyotard. The philosophy of dialogue and "irrational rationality" of J. Derrida had an enormous influence on the development of pedagogical practice, causing the appearance of specific educational technologies focused on the development of critical thinking and led to the realization of the idea of transition from knowledge model of educational content to activity learning approach. The need of society for specialists capable of solving universal problems, not tied to a particular subject, ready to learn, and thus change the existing knowledge structure several times during life corresponded to the concept of postmodernism, which saw the world as an open problem 
field outside the certainty of final truths and values. However, the traditional relationship of pedagogy and philosophy changed in the late XX century, when the stable development of pedagogical knowledge began to be influenced by new trends of globalization and internationalization of higher education. The phenomenon of globalization, which fundamentally changed the understanding of the fundamental values of civilization, not acquired understanding of the humanities, which created a fundamentally new situation in pedagogy. It appeared beyond the philosophical thought of innovation that can adequately reflect the needs of educational theory in its relations with educational practice. Such circumstances have led to significant changes in the development and functioning of education systems, prompting to analyze the educational reality as integrity of complex processes (Шатон, 2013).

One of the main concepts of philosophy, which can serve as a basis for building a modern educational paradigm under these conditions is a "philosophy of global problems" that arose in the late $1970 \mathrm{~s}$ as a set of ideas based on the objectivity of the total global relationships: socio-cultural, political, economic, religious, industrial etc. (Мясников, 2006). Analysis of the literature showed that philosophers (D. Bell, A. Peccei, P. Sorokin) determine as a key purpose of pedagogical science the search of unifying factor, the possible ways and approaches that promote interaction of knowledge, coordinate and consolidate integration processes in education to address global problems affecting the vital interests of all humanity and each individual; act further objective factor of world development and the existence of modern civilization; to overcome which require the efforts of all nations or most of the world population; unresolved which could lead to the inevitable consequences for the life of all mankind and of each individual (Волкова, 2008).

Scientists believe that timely answer of pedagogical science on global challenges is a concept of global education; based on the fundamental idea of development new, holistic vision and perception of the world, human place in the interconnected and rapidly changing environment, by filling content of the educational process with humanistic values. The concept of global education was first proved in the USA by R. Henvi and J. Botkin (Боткин, 1983; Хенви, 1994). Over the last decades, education has become a global object and subject of research by pedagogues, psychologists and philosophers, particularly in the following areas: the main component of global education (J. Tucker), goals and objectives of global education (S. Laimy), a global education methods (U. Knipp), evolutionary approaches to global education (I. Ilyin, A. Ursul); education of globally-oriented personality of “cosmopolitan" (N. Berdyaev, S. Bulgakov, V. Buriak, V. Kremen, V. Kudin, V. Soloviev, V. Vernadsky).

The most popular in educational society are two models of global education developed by R. Henvi and J. Botkin, which did not contradict, but complement each other. They see the world as a whole, a huge global community, which exists as a system of interrelations and interdependence. These models based on the principles of globalism, holism, humanism and multidisciplinary approach that open up new global perspectives. According to R. Henvi, freedom of individual's self-determination in culture expands his mental capabilities, making him an independent "citizen of the world" (Хенви, 1994). Hence, the essence of global education researcher bases on the so-called "planetary dimensions": forming an objective outlook, examining the state of the planet, the development of cross-cultural competence, understanding the dynamics of global processes and awareness of choice. At the same time, J. Botkin developed his model of globallyoriented education upon beliefs that traditional education aims at unconscious adaptation to 
reality, and humanity should move to a conscious foresight that is inherent in the innovative approach that is unity of the two aspects - foresight and ownership. However, prediction is interpreted by him as the ability to cope with new situations, anticipate events, to link the past with the present and future, to evaluate the effects of current events and solutions, create new alternatives and to share responsibility for decisions. Instead, ownership is seen as the capacity for cooperation, dialogue, understanding and empathy, improving communication skills (Боткин, 1983).

The origins of the interpretation of "global education" phenomenon are found in the documents of international organizations, dating from the second half of the XX century, namely UNESCO Recommendation concerning education for international understanding, cooperation and peace, human rights and fundamental human freedoms (1974); Declaration and Plan of Action on the UNESCO Education for Peace, Democracy and Human Rights (1995); Resolution of the UN General Assembly "Millennium Goals" (2000). It must be emphasized that all these documents to some extent shaped the concept of "global education", which found its full reflection in the "Maastricht Declaration on Global Education" (2002). In it states that global education is aimed at understanding the realities of the globalized world and its development as a society of justice and equality for all. Global education is an interdisciplinary phenomenon combining approaches of: 1) developing education; 2) legal and pacifist education; 3) conflict studying; 4) multicultural, civic and environmental education (Global Education, 2003).

Research shows lack of pedagogical approaches to the development of competences required in future professional activities to address pressing global issues, including: 1) improving living conditions and reducing poverty; 2) achieving sustainable forms of interaction between human and the environment; 3) development of global trade; 4) addressing the epidemiological spread of disease; 5) creating conditions for lasting peace and security. Thus, preparing students for work in difficult and controversial globalized world is defined as the main task of global education, which, is now gaining significant momentum in the development and implementation of teaching practices in a global pedagogy (Edwards, Usher, 2000). Within the context, interesting is one of the ideas of critical thinking pedagogy by a Brazilian philosopher P. Freire, that the main task of pedagogy is to educate a person to "decoding" reality (Freire, Macedo, 1987). Based on this idea we can make assumptions about the need for new pedagogical approaches to the interpretation of contemporary reality, because within globalization technological capabilities of distribution of certain well-established phenomena, structures and processes of reality are greatly enhanced and students (in the broadest sense) need help in deciphering of massive information flow and making responsible decisions based on critical thinking. The necessity of global pedagogy, according to researchers of educational globalization (G. Edwards, R. Robertson, R. Usher), due not only request a change in the labour market and the emergence of industry based on the production of knowledge and information, but also the very logic of pedagogical knowledge. The study showed that in 1960s the representatives of various pedagogical scientific schools expressed the need to change teaching knowledge model that no longer met the needs of society. By the time teachers in different parts of the world has accumulated a substantial potential for the development of a new didactic model, calling it developing, active, reflexive, critical thinking, etc. In most Western European and North American countries was recognized a didactic model, based on critical thinking, active learning methods and common knowledge construction in the form of a dialogue between students and teachers (Giroux, 1994). 
However, the educational practice proves that modern educational models do not fully meet the challenges of globalization and the demands of both customers and consumers of education market, representing the society as a whole rather than its individual groups. In the process of transnationalization of education the diverse learning environment is formed in which interact students and teachers from around the world. The diversity of the student community requires the teacher's possession of intercultural skills and specific teaching techniques. It is very important to consider the fact that the transfer of educational technology from one cultural space to another should take into account the cultural specificities of the space, i.e. providing a so-called "cultural sensitivity", beginning with the formation of the idea of future recipients (Dimmock, Walker, 2000). In 1993, American personality theorist of intercultural education M. Bennett developed a "model of intercultural sensitivity", which outlines the six steps of cross-cultural sensitivity forming, from ethno-centric to ethno-relativistic thinking. The author defines ethno-centric worldview as "experiential awareness of culture" being the center of reality "in which obtaining by a person beliefs and behavioral clichés in the process of socialization are undeniable". In contrast, the phenomenon of ethno-relativistic worldview allows perceiving their own beliefs and behavior as only one of much possible existence of viable models (Bennett, 1993). This process happens through a phased transformation of consciousness by the proposed scheme, where are three ethno-centric stage that represent ways to overcome cultural differences through denial of its existence by enhancing the protective functions against it and minimizing its importance, i.e.: 1) denial; 2) protection; 3) minimization; and three ethno-relativistic stages that are ways of cultural differences finding by adopting its importance through adaptation prospects for its recognition and integration of holistic concept of cultural differences in the definition of identity, i.e. : 1) perception; 2) adaptation; 3 ) integration.

\section{Understanding the differences}

\begin{tabular}{|c|c|c|c|c|c|}
\hline \multicolumn{2}{|c|}{ Ethno-centric stages } & \multicolumn{3}{|c|}{ Ethno-relativistic stages } & \multirow[b]{2}{*}{ Integration } \\
\hline Denial & Protection & Minimization & Perception & Adaptation & \\
\hline
\end{tabular}

Fig. 1. The model of intercultural sensitivity (by M. Bennett)

According to the model, the path that person chooses for interpretation and understanding of cultural differences, determines the direction of his outlook formation. In our opinion, the importance of this model is that it helps clarify and explain the way in which the international cross-cultural experience can ease the process of transforming the outlook of a specialist and help overcome his cultural ignorance in the education and training abroad within transnational individual mobility. The need for intercultural communication during foreign internships causes some pressure to change the individual outlook, which is due to the inability of traditional ethno-centric thinking adequately act in such circumstances, which is to build stable social relationships with carriers of other cultural experiences, overcoming cultural boundaries. That is why cooperation with other cultural contexts has become a key element in the process of transformation of ethnocentric to the ethno-relativistic identity of the specialist which is most effective during learning or training abroad. 


\section{CONCLUSIONS}

In conclusion, it can be assumed that modern education has become dependent on the specifics of the educational system operation and practice of educational process in the context of globalization and internationalization of education. The concept of global education aimed at overcoming the contradictions that is the lack of adequate teaching approaches corresponding to the current level of educational systems development caused by globalization, the emergence of transnational providers on the education market, rapid development of distance and virtual education.

The study showed that the philosophical and pedagogical basis of transnational higher education development serve postmodernism and postnonclassical science. Postmodern philosophy is seen as response to challenges in science and education that took place in the second half of the XX century. As a general cultural phenomenon, it has such features as challenge to conventions, mixing styles, tolerance of uncertainty, the emphasis on diversity, acceptance of innovation and change. According to postmodern philosophers, the content of education should be based on the relativity of truth and diversity, rejecting one of the major assumptions of modernism - the separation of culture to the progressive and regressive, high and low, as reflected in modern educational practice. A practical embodiment of such attempts in education is the introduction of multicultural approach, critical pedagogy, and global education. Of particular importance to the appeal of postmodernism gets its epistemological provisions under which it denies universal theory of modern pedagogy and its ethno- and anthropocentrism. According to postnonclassical theory, on which is based the idea of education transnationalization, the objects of study are complex, multi-level, open, non-linear systems that evolve and own a multiplicity of possible scenarios.

\section{REFERENCES}

1. Bennett, M. (1993). Towards ethnorelativism: A developmental model of intercultural sensitivity. In: Paige, M. (Ed.) Education for intercultural experience. Boston, MA : Intercultural Press, pp. 21-72.

2. Dimmock, C., Walker, A. (2000). Globalization and societal culture: redefining schooling and school leadership in the twenty-first century. Compare, Volume 30, No 3, pp. 303-312.

3. Edvards, R., Usher, R. (2000). Globalization and Pedagogy. Space, Place and Identity. London, New York : Routledge, $192 \mathrm{p}$.

4. Freire, P., Macedo, D. (1987). Literacy: Reading the Word and the World. London : Routledge \& Kegan Paul, 184 p.

5. Giroux, H. (1994). Toward a Pedagogy of Critical Thinking. In: Walters, K. (Ed.). Rethinking Reason: New Perspective in Critical Thinking. Albany Suny Press, pp. 199204.

6. Global Education in Europe to 2015: Strategy, Policies and Perspectives. (2003). In: O'Loughling, E., Wegimont, L. (Eds.) Outcomes and Papers of the Europe-wide Global Education Congress at Maastricht, the Netherlands, 15-17 November 2002. The NorthSouth Centre of the Council of Europe : Lisbon, 202 p.

7. Боткин, Д. (1983). Инновационное обучение, микрокомпьютеры и интуиция [Innovative Education, Microcomputers and Intuition]. Перспективы. Вопросы образования [Perspectives. Education Issues], No 1, pp. 39-47 (in Russian). 
8. Вознюк, О., Дубасенюк, О. (2009). Цільові орієнтири розвитку особистості у системі освіти: інтегративний підхід [Purposeful Directions in Personality's Development in the System of Education: Integrative Approach]. Житомир : Вид-во ЖДУ ім. І. Франка, 684 p. (in Ukrainian).

9. Волкова, Т. (2008). Философские основания глобальных проблем современного общества. Учебное пособие [Philosophical Bases of Global Problems of Contemporary Society. Tutorial]. Челябинск : Изд-во ЧелГМА, 44 p. (in Russian).

10. Мясников, В. (2006). Глобализация и образование в XXI веке [Globalization and Education in the XXI Century]. In: Основнье тенденции развития образования в современном мире: Сборник научных трудов Института теории и истории педагогики РАO [Main Tendencies of Education Development in the Modern World: Collection of Scientific Papers of the Institute of Theory and History of RAE]. Москва, pp. 160-175 (in Russian).

11. Поздняков, В. (2004). Взаємодія освіти і науки як шлях до становлення постнекласичної освіти [Interaction of Education and Science as a Way to Postnonclassical Education Development]. Наукові $i$ освітянські методологї $i$ практики [Scientific and Educational Methodology and Practice]. К. : ЦГО НАН України, pp. 398-496 (in Ukrainian).

12. Хенви, Р. (1994). Достижимая глобальная перспектива [An Attainable Global Perspective]. Рязань : Изд-во РГПУ, 92 р. (in Russian).

13. Шатон, Г. Педагогика vs образование. Метафора глобализации и педагогика [Pedagogy vs Education. The Metaphor of Globalization and Pedagogy]. Retrieved 23.01.13 from : http://www.newsletter.iatp.by/ctr6-13.htm (in Russian). 